\title{
Brief Analysis on Cross-cultural Communication
}

\author{
Jun Xu \\ English Department of Dezhou University, Shandong, China \\ Email: xujun56cn@yahoo.com.cn
}

\begin{abstract}
It is impossible to completely separate the theoretical study of intercultural and cross-cultural communication. Gudykunst states that before the late 1970s when he began his doctoral studies, there were few, if any, reliable and valid theories for the study of either type of communication. Perhaps then there were only trends in research. As the study of intercultural and cross-cultural theories has matured many new actual theories have been developed, tested., and confirmed or disconfirmed. Still more cross-cultural theories will develop over time which can be tested in a reliable and valid manner.
\end{abstract}

Index Terms - culture, cross-cultural communication, intercultural communication, principle

\section{DEFINING INTERCULTURAL AND CROSS-CULTURAL COMMUNICATION}

The most intercultural communication may be between identical twins, then fraternal twins, followed by brothers and sisters. If the twins meet twins from a different culture and converse and interact, whether unintentionally or purposefully, then intercultural communication occurs as in the presence of another, all behavior is communicative. Most intercultural communication occurs within an interpersonal setting. In this way, both intercultural and interpersonal communication is complementary. When researchers want to compare or contrast how the twins from different cultures interact interculturally, then a cross-cultural communication study occurs. While the definition that cross-cultural communication informs the theoretical study of comparative and contrastive cultures and cultural variables, an alternative definition of cross-cultural communication is communication which takes place between members of whole cultures in contact, or between their cultural spokespersons or representatives. William B. Gudykunst (2003) identifies both the study of intercultural communication and cross-cultural communication as segments of intergroup communication. Academic fields with a special interest in cross-cultural communication research include anthropology, communication, international relations, psychology and sociology.

Intercultural and cross-cultural investigations may include such areas as attitudes, beliefs, cognition, cross-cultural business and training, journalism, language and linguistics, mass media, nonverbal cues, organizational culture, perceptions, stereotypes, thought-patterning and values, Gudykunst and Lee (1977) argue that among the following elements of communication several can be accurately considered cross-culturally as theoretical constructs for current investigation: 1. cultural variability including the spectrum of similarities and differences, plus horizontal versus vertical national cultural dimensions; as identified by scholars such as Geert Hofstede, Michael Harris Bond, Robert Ingelhart, and Shalom Schwartz; 2. individualism-collectivism with the study of ingroups and outgroups; as well as individualistic versus collectivistic values and 3. self-construals or the ways that people see themselves.

Additionally, Gudykunst and Lee (1977) propose other theoretical dimensions of cultural variability such as low and high context culture, initially introduced by Edward T. Hall in his 1976 book Beyond Culture; face-negotiation theory, proposed by Stella Ting-Toomey in 1985, which illustrates how members of cultures manage high or low face and conflicts; the conversational constraints theory, developed by Young Yun Kim in 1993 as goal or task oriented and coordinated conversations in relationships; the expectancy violations theory, proposed by J. K. Burgoon in 1978, by which guidelines are delineated for appropriately expected behavior in communicative situations; the anxiety/uncertainty management theory (AIM), developed by Gudykunst in 1995, which focuses on effective interpersonal and intergroup communication as it incorporates how communicators manage anxiety and uncertainty processes; and the communication accommodation theory (CAT) which Gudykunst also includes in theoretical intercultural communication studies, occurring between people of different ingroups and outgroups by assessing their language, nonverbal behavior, and paralanguage in communicative situations.

\section{PRinciples or CRiteria Guiding Cross-CUltural Communication Researchers}

Stephen McDowell (1997) stipulates that a field of inquiry is not just a series of substantive topics, but a set of core problems, concepts, theories, and methods and an ongoing discussion among practitioners.

Various principles or criteria guide researchers in studying intercultural and cross-cultural communication. Among these are the cultural principles identified by Michael H. Prosser in his 1978 book, The Cultural Dialogue, of similarities and differences, the role of conflict and conflict resolution, communicative cultural control and power, the impact of technology and especially information technology, cultural stability and cultural change, cultural imperialism and cultural dependency or interdependency. Steve J. Kulich (2007) recommends a nine multi-level analysis of culture model for future cross-cultural research: 1. culture as propagated mythic ideals, 2. as mainstream promotion or mass 
trends, 3. as model-citizen norms, 4. as expected behavior mechanics, 5. as integrated meshworks, 6. as mediated metaphors, 7. as mindless personal responses to familiarity, 8. as personal matrix options, and 9. as personalized meaning. In the context of social science research, Kulich proposes than an integrated grid can be developed in the cross-cultural study of culture and communication and they can be studied at the cultural, subcultural, co-cultural, contextual, and individual levels of culture. An integrated grid could include historically transmitted socialization, socially constructed perceptions within the context of cultural groups and personally, and reflective and relative senses of meaning.

Gudykunst and Lee (1977) offer five approaches to incorporate culture into communication theories: Culture can be viewed as 1.a part of the communication process in theories or 2. as creating culture. 3. Theories designed in one culture can be generalized to other cultures. 4. can be generated to explain communication between people from different cultures. 5. or to explain how communication varies across cultures. For cross-cultural theory construction and analysis, they believe that in addition to standard social science methods such as logical consistency, explanatory power, and parsimony, the following should also be added: including more than one dimension of cultural variability, linking dimensions of cultural variability directly with the cultural norms and rules that influence the communication behavior being explained, and avoiding oversimplifying the process or inappropriately coupling the way that the cultural variables influence cultural norms and rules or the reverse.

\section{ILLUSTRATIVE EXAMPLES OF EFFECTIVE CROSS-CULTURAL COMMUNICATION RESEARCH}

An early and longitudinal example of major cross-cultural research efforts include Charles E. Osgood's CrossCultural Universals of Affective Meaning Project to develop near cultural and language universal theories in approximately fifty cultures, In this multinational study, 100 teenaged boys in each culture were chosen to assess 100 terms for their understanding of goodness or badness, power or lack of power, and swiftness or slowness through a seven point semantic differential scale. This study tested and confirmed the hypotheses that regardless of language or culture, human beings use the same qualifying and descriptive framework in allocating affective meanings of concepts which involve attitudes, feelings, stereotypes and values.

Desmond Morris'(1979) study of middle-aged male usage of nonverbal gesture cues in twenty-five European cultures, described in his book Gestures, hypothesized and confirmed that middle-aged men living closer to the Mediterranean Sea, and already strongly fixed in their own national culture behaviors, would utilize far more exaggerated and bolder gestures than would those middle-aged men living in the northern European or Scandinavian countries. Also, the hypothesis that the former group would have more gestures with sexual implications than the northern European or Scandanavian cultures was generally confirmed. Later, in his 1994 book, Bodytalk: A World Guide to Gestures, more cross-cultural nonverbal studies were significantly explored in a much wider geographical range.

In the 1974 bicultural research conference in Japan, it was hypothesized that Japanese participants would be more task-oriented and the Americans would be more process-oriented. Perhaps, not surprisingly, it was found that the younger Japanese and American participants were more process-oriented, while the older Japanese and Americans were more task-oriented.

One of the most important cross-cultural studies of national attitudes and values has been Dutch sociologist Geert Hofstede's (1980) analysis of 116,000 responses to his earlier IBM questionnaire, first reported in his 1980 book Culture's Consequences and later modified in a second edition in 2001. Based on this study, he (1980) initially proposed the development of four national cultural dimensions, uncertainty avoidance, power distance, individualism versus collectivism, and masculinity versus femininity, with a fifth dimension incorporated by Michael Harris Bond, in 1987, called Confucian dynamism or later short-term versus long-term orientation. Uncertainty avoidance specifies the level to which members of a national culture avoid or accept uncertainty; power distance is the extent to which less powerful members of organizations and institutions accept unequal distributions of power. Masculinity versus femininity, more recently described as aggressiveness versus nurturing, emphasizes how a national culture manages its gender issues. Individualism versus collectivism, initially proposed by cross-cultural psychologist Harry C. Triandis (1995), focuses on whether members of a national culture are more oriented to individual versus collective or communitarian values. The Chinese Culture Connection in 1987 proposed that Hofstede's western bias needs to be supplemented by a Chinese methodological bias of Confucianism. This cultural variability dimension has three aspects: status relationships, integration or harmony with others, and moral discipline.

\section{ILlustrative Problems IN WeSTERn VERSus NON-WeSTERn CROSS-CULTURAL COMMUNICATION RESEARCH}

Many early cross-cultural studies focused on comparisons between Americans/ Japanese, Americans/Europeans, or between American/Soviet cultural patterns. More recently considerable research has emphasized bipolar cultural aspects between the Americans/Chinese or Chinese and other Westerners. Bond(2008) recommends that while these bicultural studies are useful, including those by cross-cultural psychologists, they are primarily descriptive as they use Western research methods to deal with indigenous cultural patterns. He urges cross-cultural researchers to move toward more pan-cultural studies, as Hofstede's studies have done, and that for serious reliability, at least ten cultural groups are 
needed when using standard social science statistics.

Hwang Kwang-Kuo (2009) also argues that the development of social scientific cross-cultural research in the indigenous Asian setting is problematic because western social science methods are not always appropriate to study indigenous Asian cultural factors. He (2009) believes that western social science theories, or the scientific micro-world versus the indigenous Asian life-world for intellectuals in non-Western countries has serious limitations as the philosophy of science for constructing a scientific microworld is essentially a product of alien cultures which is inconsistent with practical Asian cultural traditions. Thus, a cross-cultural communication researcher must construct a tentative theory to solve scientific problems caused by 1 .inconsistencies between western theories and the observed phenomena or results of experiments in more traditional Asian societies, 2.contradictions within a system or a theory, and 3.conflicts between the two types of theories. For example, formal justice in western scientific cross-cultural studies includes such basic elements as authority in an unequal relationship but does not practically consider the notion of Confucian respect for the superior in determining what justice is. Referring to cross-cultural communication studies for Chinese scholars as illustrative, GUAN Shije (1995) of Peking University notes several problems for China, and by implication for other Asian cultures: 1. More dialectical research is conducted than empirical studies, 2. Too much research is conducted in individual disciplines rather than on an interdisciplinary basis, 3. More general introductions are provided than on specific topics with Chinese characteristics, 4. More Sin0-US research is done than comparing China with other countries, 5. More international studies than domestic cross-cultural research of different Chinese communities in the mainland, Hong Kong, Taiwan and in the Chinese diaspora are conducted, He argues that this Chinese unitariness of research methodology has been a bottleneck in restraining further in-depth cross-cultural Chinese and Asian communication research.

\section{SUMMARY}

It is impossible to completely separate the theoretical study of intercultural and cross-cultural communication. Gudykunst (2003) states that before the late 1970s when he began his doctoral studies, there were few, if any, reliable and valid theories for the study of either type of communication. Perhaps then there were only trends in research. As the study of intercultural and cross-cultural theories has matured many new actual theories have been developed, tested, and confirmed or disconfirmed. Still more cross-cultural theories will develop over time which can be tested in a reliable and valid manner. New social science statistical measurements can help researchers hypothesize and test these theories, adding to the mature development of cross-cultural theoretical constructs.

\section{REFERENCES}

[1] Bond, M.H. (2008). The psychology of the Chinese people. Hong Kong: Chinese University Press.

[2] Chen, G-M. \& Starosta, W. J. (2005). Foundations of intercultural communication. Lanham, MD: UPA.

[3] Guan S.J.(1995). Cross-cultural communication. Beijing: Peking University Press.

[4] Gudykunst, W. B. (Ed.) (2003). Cross-cultural and intercultural communication. Thousand Oaks: Sage.

[5] Hofstede, G. (1980). Culture's consequences. Beverly Hills, CA: Sage Publications.

[6] Kulich, S.J. \& Prosser, M.H. (Eds.). (2007). Intercultural perspectives on Chinese communication. Shanghai: Shanghai Foreign Language Education Press.

[7] Hwang K.K.(2009). The development of indigenous counseling in contemporary Confucian communities. The Counseling Psychologist. Issue 37, No.7:930-943.

[8] Lee, C.M. \& Gudykunst, W.B.(1977). Attraction in initial interethnic interactions. New Brunswick: Transaction Periodicals Consortium.

[9] McDowell, S.D.(1997). Globalization, liberalization and policy change: a political economy of India's communications actor. New York: St. Martin's Press.

[10] Morris, D.(1979). Gestures. New York: Stein and Day.

[11] Morris, D.(1994). Bodytalk: the meaning of human gestures. New York: Crown Trade Paperbacks.

[12] Prosser, M.H. (Ed.). (1973). Intercommunication among nations and peoples. New York: Harper and Row.

[13] Prosser, M.H. (1978). The cultural dialogue: An introduction to intercultural communication. Boston: Houghton Mifflin. (1985; 1989). Washington, D.C. SIETAR International.

[14] Prosser, M.H. \& Sitaram, K.S. (Eds).(1999). Civic discourse: Intercultural, international and global media. Westport, CT: Ablex.

[15] Samovar, L. A., Porter, R.E. \& McDonald, E. R. (2008). Intercultural communication: A reader. 12th edition. Belmont, CA: Wadsworth.

[16] Sitaram, K.S. \& Prosser, M.H. (Eds.). (1998). Civic discourse: Multiculturalism, cultural diversity, and global communication. Westport, CT. Ablex.

[17] Triandis, H.C. (1995). Individualism \& Collectivism. Boulder: Westview Press.

Jun Xu was born in Binzhou, China in 1956. She majored in English Linguistics and Literature in the department of Foreign Studies, Liaocheng University, China in 1976-1979 and completed equivalent M.A. degree courses on English Linguistics and 
Literature in Shandong University, Jinan, China in 2002. Supported by Chinese State-funded students studying abroad Project, she was a full-time Visiting Scholar in School of English Study, Nottingham University, UK in 2002-2003.

She is currently an associate professor and the Director of the School of Foreign Languages, Dezhou University, Shandong, China. She has written "Study on analysis of Students' Speaking Error and PETS-Instruction of Students' Speaking Error Analysis in English Speaking Teaching", Vladivostock, Russia: Intelligent Potential of Advanced Education-Development of Russian Far East and Asia-Pacific Development, 2009; "Experiencing in Glamorous Language World", Yantai, China: Journal of Yantai Education Institute, 2004; "Backwash Effect on Current High School English Teaching in light of NMET", Shandong Enterprise Education, 2007; Translation works: The Cambridge Illustrated History of British Theatre', Shandong Pictorial Press. 2006. Her research interests include cross-cultural communication and English language teaching.

$\mathrm{Ms} \mathrm{Xu}$ is the Director of English Language Institute of Shandong Province. Her publications as "Antidotes to Computer Virus" was awarded the third prize by the $8^{\text {th }}$ Dezhou Municipal Excellent Social Scientific Achievements in 1995; "Influence of English and American Language and Culture on Chinese Language" was awarded the third prize by the $9^{\text {th }}$ Dezhou Municipal Excellent Social Scientific Achievements in 1996; "Basic Exploration on Fast-reading Teaching" was awarded the third prize by the $17^{\text {th }}$ Dezhou Municipal Excellent Social Scientific Achievements in 2004. 